\title{
Twenty Years of Tariff Manipulation
}

IN A discussion of the ever present tariff problem one often reflects on the determining factors in the tariff policy of our country. The correspondence of Justin S. Morrill, ardent protectionist and author of the Morrill Tariff Act of $186 \mathrm{x}$, sheds considerable light upon this subject. The material covers the period between 1867 and $\mathrm{I} 897$. It has been acquired by the Baker Library through the courtesy of John Spargo, President of the Vermont Historical Society.

Though the tariff policy of the United States has undoubtedly been tinged with the spirit of protectionism since its inception, the country experienced a low tariff period between 1846 and 1857 . The crisis in 1857, however, was a factor in bringing about a decided change in policy and it was at this time that Mr. Morrill, a representative from Vermont, entered the conflict with the Tariff Act of I86I, known as the Morrill Tariff Act.

Mr. Morrill and his supporters contended that the act in question was an attempt to restore the duties to the level established by the Act of 1846 , while incidentally substituting specific for ad valorem duties. This change, however, actually involved a material increase in rates which it was hoped would secure the support of Pennsylvania and some of the Western states for the Republican Party in the ensuing election, as the duties on iron and wool were thereby increased. The manufacturing interests themselves were at this time indifferent to the tariff, Morrill himself declaring later that the Act of I 86I "was not asked for and but coldly welcomed by manufacturers who always and justly fear instability."

With the advent of the Civil War and the urgent need for funds, the tariff duties were increased by changes carried out in 1862 and I 864. Justin Morrill, who was Chairman of the Ways and Means Committee in $1864-65$, argued that this additional protection was needed to offset the internal taxes imposed on domestic producers. The enactments were hurried and ill considered, but curiously enough the general level of the tariff which resulted from these laws came to form the starting point for a permanent tariff system. Hence, as Professor Taussig in his Tariff History of the United States so aptly expresses it, "The extreme protective system, which had been at the first a temporary expedient for aiding in the struggle for the Union, adopted hastily and without any thought of deliberation, gradually became accepted as a permenent institution. From 
this it was a short step, in order to explain and justify the existing state of things, to set up high protection as a theory and a dogma."

The Morrill papers bear on the period of readjustment which followed the war; and the attitude not only of.individual industries but of the state governments themselves is exemplified in their demands, not alone for the continuation of war tariff, but for even higher duties whenever such duties could be secured.

By 1870 the situation had become critical. The West was loud in its demands for tariff reform and there was a general plea for a reduction in taxes. As a matter of fact, the Government was embarrassed by a large surplus in the revenue and a reduction in tariff rates seemed the logical solution of the problem. However, this decision was not at all pleasing to the sugar interests, which immediately bombarded their representatives in Congress with requests for a continuation of the high duties.

Among the Morrill papers is a joint resolution, dated February 5, I 870 , of the legislature of the State of Louisiana instructing their Senators and Representatives in Congress "to use their best exertions against any reduction on the duty now fixed by law on Sugar and Molasses." Louisiana at this time, though our leading sugarproducing state, yielded hardly one tenth of the sugar consumed in the country, and though the tax of two cents a pound did not prevent the importation of raw sugar, it did tend to equalize the existing competitive conditions, as the climate was more favorable for the growth of sugar cane in Cuba and Java than in Louisiana.

However, the refining interests took yet another view of the situation, crying loudly for a revision of the tariff rates, i. e., lower duties on raw sugar and higher duties on the refined product. As early as 1868 the refiners were insistent in their demand for revision. Mr. Hugh Camp, a refiner himself, addressed a letter to Mr. Morrill, then a United States Senator, dated March I8, I868, in which he asserted "if this Tax and Tariff continue for two years more, the Refining interest of the country will be as dead as Shipbuilding is today."

Two years later, as representative for the refining group, Mr. Camp while in Washington wrote to Mr. Morrill, and in a letter dated July I I, I870, asked "leave to say as concisely as possible that the passage of the Senate bill on sugar would bring utter ruin upon our industry, and inevitably transfer it to foreign shores; if it could be proved that by this course the masses would get their sugars cheaper, it might be well to sacrifice us, but this cannot be 
shown; but we can show that while we are sacrificed, foreigners and only foreigners are benefited."

Although the sugar group did not secure such high protection in the seventies, their efforts were not abated. Two important events occurred in the sugar industry in the twenty years following - a development in large-scale production, and a closer combination among the refiners - which culminated in the sugar trust. By 1883 the tariff on refined sugar exceeded that of raw sugar by about one cent a pound. As the improvements in refining had decreased the cost of converting raw sugar to much less than this figure, the duty practically prohibited the importation of refined sugar.

The petitions of the sugar group are not isolated phenomena in Mr. Morrill's correspondence, however. His Vermont constituents in I 870 were loud in their demands for a specific duty on marble rather than an ad valorem. The chemical industries at this time begged Mr. Morrill to "come to the rescue and save us, if possible" and declared that business is "su close that almost any reduction of the present tariff rate on imported sulphur would destroy it." The manufacturers of iron and steel wire complained that cut wire was paying a duty of "only 35 per centum ad valorem, though this class of wire is more advanced as to labor and cost than the wire from which it was made." The equally disgruntled cries of American publishing houses indicated that they too were desirous of a tariff change. The importers, Little Brown and Company, Appleton and Company, and Scribner and Company, sent a special petition to the Committee of Ways and Means asking for a specific duty of 15 cents per pound on books. Most of the other importers thought it ought to be at least 20 cents per pound. One thing, however, was clear: "The tariff on books ought to be and must be specific if the Government is ever to collect it with any degree of fairness."

Twenty years later Mr. Morrill was still the recipient of hundreds of letters relating to tariff rates. The secretary of the National Association of Wool Manufacturers wrote from Boston on April 25, 1896: "Perhaps I ought to say in conclusion that the manufacturers are extremely anxious to avoid any antagonism to the wool growers up to the time when the actual framing of a new tariff law shall have been begun. They realize that when the time comes, the antagonism is inevitable and their theory is that the longer the expression of it is delayed, the more likely it is to be minimized."

Mr. Morrill's correspondence is not lacking in letters and petitions setting forth the other side of the story, and during the sugar 
controversy in 1870 a sheaf of petitions asserted that "it is due to the labor of the nation that taxation be reduced and equalized as rapidly as a due regard for the National faith will permit." They asked for an abolition of the duties on tea and coffee, and a reduction in the duty upon sugar and molasses.

It seems remarkable that any concerted line of action could be decided upon, or any reconciliation in the viewpoints brought about. However, witness the McKinley Tariff in I8go which, though it admitted raw sugar free, was not deaf to the "interest of the State of Louisiana" as a bounty equivalent to the tax of two cents was given to the sugar producers. Time too has shown that Mr. Morrill successfully served 44 years in Congress and though a protectionist at heart, was not, as we have seen, indifferent to the arguments of the free-trade exponents.

Besides the Morrill papers from which the above excerpts have been given, the Baker Library was fortunate in being able to purchase about a thousand books and documents from Mr. Morrill's library in Stafford, Vermont. The collection contains annual reports, Congressional documents, and official publications relating to institutions in which, as a member of various Senate committees, Mr. Morrill was interested.

\section{Paper Money for a Panic}

THE specimens of Portland Clearing House Association currency reproduced on the opposite page were issued during the panic year of I907. This was primarily a money panic, with banks throughout the United States unable to meet the demands of their depositors for currency payment. To bridge the situation at that time, the Portland Clearing House Association pre-empted the rights of a "Bank of Issue" and, as a temporary currency, issued clearinghouse notes. In issuing these notes, the members of the Portland Clearing House Association, as stated on the certificate, deposited as security with a Clearing House Committee, their own customers' notes and other negotiable instruments which in turn were secured by wheat, grain, canned fish, and lumber, as evidenced by warehouse receipts or shipping documents.

The larger notes, like the twenty-dollar note in the illustration, were issued first but later recalled. It is supposed that their recall 